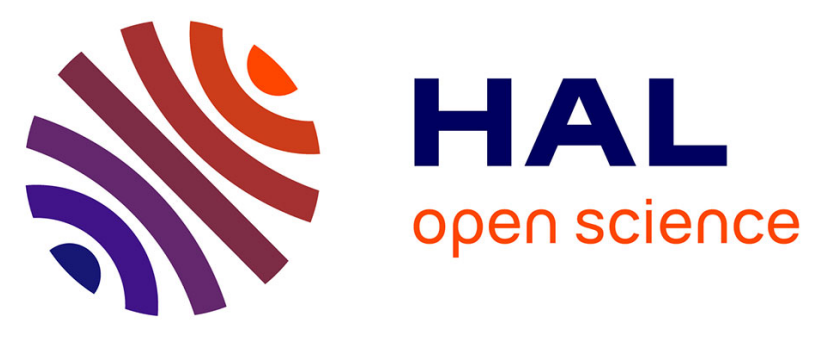

\title{
Milk fat globules as a source of mammary microRNA
}

Daiane Lago Novais, Karol Pawlowski, José Pires, Lenha Mobuchon, Sébastien Bes, Patrice Martin, Christine Leroux

\section{To cite this version:}

Daiane Lago Novais, Karol Pawlowski, José Pires, Lenha Mobuchon, Sébastien Bes, et al.. Milk fat globules as a source of mammary microRNA. 2016 JAM Joint Annual Meeting, Jul 2016, Salt Lake City, United States. ASAS - American Society of Animal Science American Dairy Science Association, Journal of Animal Science, 94, 2016, 2016 JAM, Joint Annual Meeting, "Animals and Science: Big Solutions for Grand Challenges", July19-23, 2016, Salt Lake City, Utah, USA. hal-02742741

\section{HAL Id: hal-02742741 \\ https://hal.inrae.fr/hal-02742741}

Submitted on 3 Jun 2020

HAL is a multi-disciplinary open access archive for the deposit and dissemination of scientific research documents, whether they are published or not. The documents may come from teaching and research institutions in France or abroad, or from public or private research centers.
L'archive ouverte pluridisciplinaire HAL, est destinée au dépôt et à la diffusion de documents scientifiques de niveau recherche, publiés ou non, émanant des établissements d'enseignement et de recherche français ou étrangers, des laboratoires publics ou privés. 


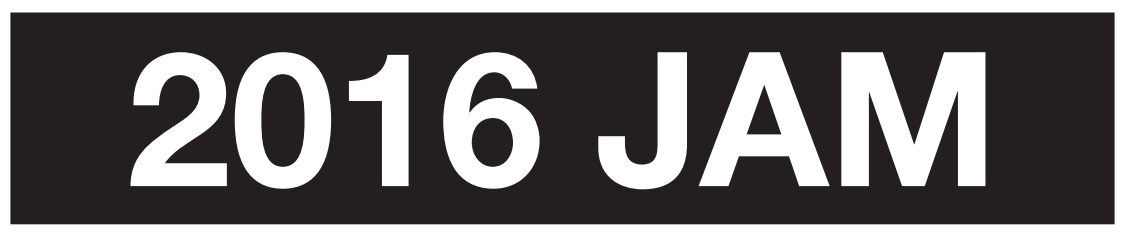

\title{
Joint Annual Meeting
}

\author{
July 19-23, 2016 \\ Salt Lake City, UT
}

American Society of Animal Science Journal of Animal Science Volume 94, E-Supplement 5

American Dairy Science Association ${ }^{\circledR}$ Journal of Dairy Science ${ }^{\circledR}$ Volume 99, E-Supplement 1 
0849 Milk fat globules as a source of mammary microRNA. D. Lago-Novais ${ }^{1,2}, \mathrm{~K}$. Pawlowski ${ }^{1}$, J. A. A. Pires ${ }^{* 1}$, L. Mobuchon ${ }^{1,3}$, S. Bes ${ }^{1}$, P. Martin ${ }^{3}$, and C. Leroux ${ }^{1},{ }^{1}$ UMR 1213 Herbivores, INRA, VetAgroSup, Saint-Genes-Champanelle, France, ${ }^{2}$ Universidade Federal da Bahia, CEP, SalvadorBA, Brazil, ${ }^{3}$ UMR1313 Gabi, INRA, AgroParisTech, Université Paris-Saclay, Jouy-en-Josas, France.

Tissue for research on mammary gland (MG) gene expression is obtained via invasive and expensive methods (biopsy or post-mortem) that limit high throughput analyses. Milk fat globules (MFG) have been used to assess the mRNA content of the mammary epithelial cells in the bovine and goat (Brenaut et al., 2012; Canovas et al., 2014) for gene expression studies. MFG is therefore a satisfactory alternative source of mammary mRNA. MicroRNAs (miRNA) are small stable noncoding RNAs involved in multiple aspects of mammary gland physiology. Whereas the use of MFG was reported in humans (Munch et al., 2013), until now MFG as the source of miRNA has not been studied in the bovine. The objective of this study was to assess MFG as a source of miRNA, and whether the latter are representative of MG miRNA expression, by comparing targeted miRNA in MFG and MG sampled from mid-lactation Holstein cows. Total RNAs were extracted from MFG $(n=6)$ and MG $(n=6)$ using TRIzol (ThermoFisher, Inc, USA). Nine miRNA (miR-29a, miR-125, miR-126, miR-141, miR-148a, miR-204, miR-223, miR-320, and $m i R-494)$ were studied by RT-qPCR. The results are expressed as fold change of MFG data relative to MG data using the $2-\Delta \Delta \mathrm{Ct}$ method and $U 6$ as internal reference. Statistical analyses were performed using a $t$ test (DataAssist ${ }^{\mathrm{TM}}$ software) and $P<0.05$ considered as significant. Among the nine miRNA chosen on the basis of the expression in MG, two were not detected in MFG whereas they were highly abundant in MG (miR-126 and $m i R-204)$, and three were significantly more abundant in MG than in MFG (miR-29a, miR-125b, and $m i R-148 a$, presenting a fold change value of $23.2,13.9$, and 8.7, respectively). Four miRNA were detected at the same level in both MFG and MG. Our results suggest that there are different mechanisms of miRNA transfer to milk. Nevertheless, it is possible that miRNA not present in MFG are not expressed in epithelial cells, but are present in other MG cell-types, and therefore not transferred to milk. In conclusion, MFG can be used as a non-invasive source of microRNA but do not reflect exactly the MG miRNome. Further research is warranted on the composition of MFG miRNome and modulation of their secretion in milk.

Key Words: bovine, microRNA, milk fat globule
0850 Consumption of endophyte-infected fescue seed during the dry period and lactation affects mammary gland gene expression in dairy cows. R. L. Baldwin ${ }^{* 1}$, C. Li ${ }^{1}$, D. M. Bickhart ${ }^{1}$, C. M. Evock-Clover ${ }^{1}$, P. Grossi ${ }^{2}$, R. K. Choudhary ${ }^{3}$, T. H. Elsasser ${ }^{4}$, G. Bertoni ${ }^{5}$, E. Trevisi ${ }^{6}$, G. E. Aiken', K. R. McLeod ${ }^{8}$, and A. Capuco', ${ }^{1}$ Animal Genomics and Improvement Laboratory, USDA-ARS, Beltsville, MD, ${ }^{2}$ Università Cattolica del Sacro Cuore, Piacenza, Italy, ${ }^{3}$ School of Animal Biotechnology, GADVASU, Ludhiana, Punjab, India, ${ }^{4}$ USDA-ARS, Animal Biosciences and Biotechnology Laboratory, Beltsville, MD, ${ }^{5}$ Istituto di Zootecnica, Università Cattolica del Sacro Cuore, Piacenza, Italy, ${ }^{6}$ Università Cattolica del Sacro Cuore, Piacenza, Italy, ${ }^{7} U S D A-A R S$, Lexington, $K Y$, ${ }^{8}$ University of Kentucky, Lexington.

Ergot alkaloids in endophyte-infected grasses inhibit prolactin secretion and reduce milk production when fed to lactating cows. However, we have shown this effect is temporal in that prepartum consumption of infected seed throughout the dry period does not inhibit subsequent milk production and, in fact, prior exposure to bromocriptine (ergot peptide) actually increases production. To identify changes in the transcriptome and pathways mediating the mammary gland's response to ergot alkaloids in the diet, RNA sequencing (RNA-Seq) was performed on mammary tissue obtained from 24 multiparous Holstein cows exposed to 1 of 3 treatments. Starting at $90 \pm 4$ d prepartum, cows were fed endophyte-free fescue seed (control, C), endophyte-free fescue seed plus $3 \times /$ wk subcutaneous injections of bromocriptine $(0.1 \mathrm{mg} / \mathrm{kg} \mathrm{BW}, \mathrm{B})$, or endophyte-infected fescue seed (I), as $10 \%$ of the diet on an as-fed basis. Mammary biopsies from 4 or 5 cows/treatment at each of 3 distinct phases were obtained: $7 \mathrm{~d}$ before dry off during the initial lactation (L1), mid-dry period (D), and $10 \mathrm{~d}$ postpartum (L2). Biopsy samples from each treatment group and phase of lactation were used to generate individual RNA-Seq libraries. Normalized reads of the RNA-Seq data were organized into technical and biological replicates before processing with the RSEM software package. Each lactation phase was processed separately with the "rsem-run-ebseq" pipeline, and genes that differed between any of three treatments were identified from program output. A large proportion of genes considered to be differentially expressed in at least one treatment with a posterior probability of differential expression greater than $90 \%$ ( $n$ $=866$ ) were found to be similarly expressed in B and I treatments, but differentially expressed from $\mathrm{C}(n=575$, total for all three phases). When phases were compared, 104 genes that were differentially expressed compared to $\mathrm{C}$ were found to be common to the L1 and L2 phases. Consistent with the production findings, networks most affected by treatments in L1 and L2 include lipid metabolism, small molecule biochemistry, and molecular transport, while in $\mathrm{D}$ networks relate more to 